\title{
Stature and Status: Height, Ability, and Labor Market Outcomes
}

\author{
Anne Case and Christina Paxson
}

Princeton University

\begin{abstract}
The well-known association between height and earnings is often thought to reflect factors such as self-esteem, social dominance, and discrimination. We offer a simpler explanation: height is positively associated with cognitive ability, which is rewarded in the labor market. Using data from the United States and the United Kingdom, we show that taller children have higher average cognitive test scores and that these test scores explain a large portion of the height premium in earnings. Children who have higher test scores also experience earlier adolescent growth spurts, so that height in adolescence serves as a marker of cognitive ability.
\end{abstract}

\section{Introduction}

It has long been recognized that taller adults hold jobs of higher status and, on average, earn more than other workers. Empirical research on height and success in the U.S. labor market dates back at least a century. Gowin (1915), for example, presents survey evidence documenting the difference in the distributions of heights of executives and of "average men." Gowin also compares the heights of persons of differing status in the same profession, finding that bishops are taller on average than preachers in small towns, and sales managers are taller than salesmen, with similar results for lawyers, teachers, and railroad employees (32).

We thank Tom Vogl and Mahnaz Islam for expert research assistance, Angus Deaton for comments on an earlier draft, and two anonymous referees for useful comments. This research has been supported by grant HD041141 from the National Institute of Child Health and Human Development and grant P01 AG005842 from the National Institute on Aging.

[Journal of Political Economy, 2008, vol. 116, no. 3]

(C) 2008 by The University of Chicago. All rights reserved. 0022-3808/2008/11603-0003\$10.00 
Height continues to be highly correlated with labor market success in developed countries. Figure 1 provides evidence from the United States and the United Kingdom that more highly skilled jobs attract taller workers. American men in white-collar occupations are an inch taller, on average, than men in blue-collar occupations. Among 30-yearold men in the United Kingdom, those working in professional and managerial occupations are 0.6 inch taller on average than those in manual occupations. Results for women are quite similar: in the United Kingdom, women working as professionals and managers are an inch taller on average than those in manual unskilled occupations.

Taller people also have higher average earnings. Table 1 presents results on the relationship between the logarithm of earnings (both weekly and hourly) and height for men and women from the National Child Development Study (NCDS), a British birth cohort study of children born in 1958; the British Cohort Study (BCS), a birth cohort study of children born in 1970; and the Panel Study of Income Dynamics (PSID), a longitudinal study of U.S. households. (The British samples, which we use later in the paper, are discussed below.) For both men and women, the relationship is striking: a 1-inch increase in height is associated on average with a 1.4-2.9 percent increase in weekly earnings and a 1.0-2.3 percent increase in average hourly earnings. In general, height is associated positively with work hours, so that the height coefficient for weekly earnings is somewhat larger than that for average hourly earnings.

The association between height and earnings is economically significant. The results for the PSID indicate that an increase in U.S. men's heights from the 25th to the 75th percentile of the height distributionan increase of 4 inches-is associated with an increase in earnings of 9.2 percent. Furthermore, this association is not driven by lower earnings of unusually short people, but instead is observed throughout the range of heights. Figure 2 shows the results of nonparametric regressions of the log of weekly earnings at age 33 on height, for white men and women from the NCDS. Although men earn more than women at all heights, the increase in earnings with height is similar for men and women.

A large number of hypotheses have been put forward to explain the association between height and earnings. In developing countries, the height premium in earnings is often attributed to the greater strength and better health that accompany height (Haddad and Bouis 1991; Steckel 1995; Strauss and Thomas 1998). In developed countries, researchers have emphasized factors such as self-esteem (Wilson 1968; Lechelt 1975; Freedman 1979; Young and French 1996), social dominance (Klein et al. 1972; Hensley 1993), and discrimination (Loh 1993; Magnusson, Rasmussen, and Gyllensten 2006). In a recent paper, Persico, Postlewaite, and Silverman (2004) suggest that boys who are taller 
NHIS 1986-94
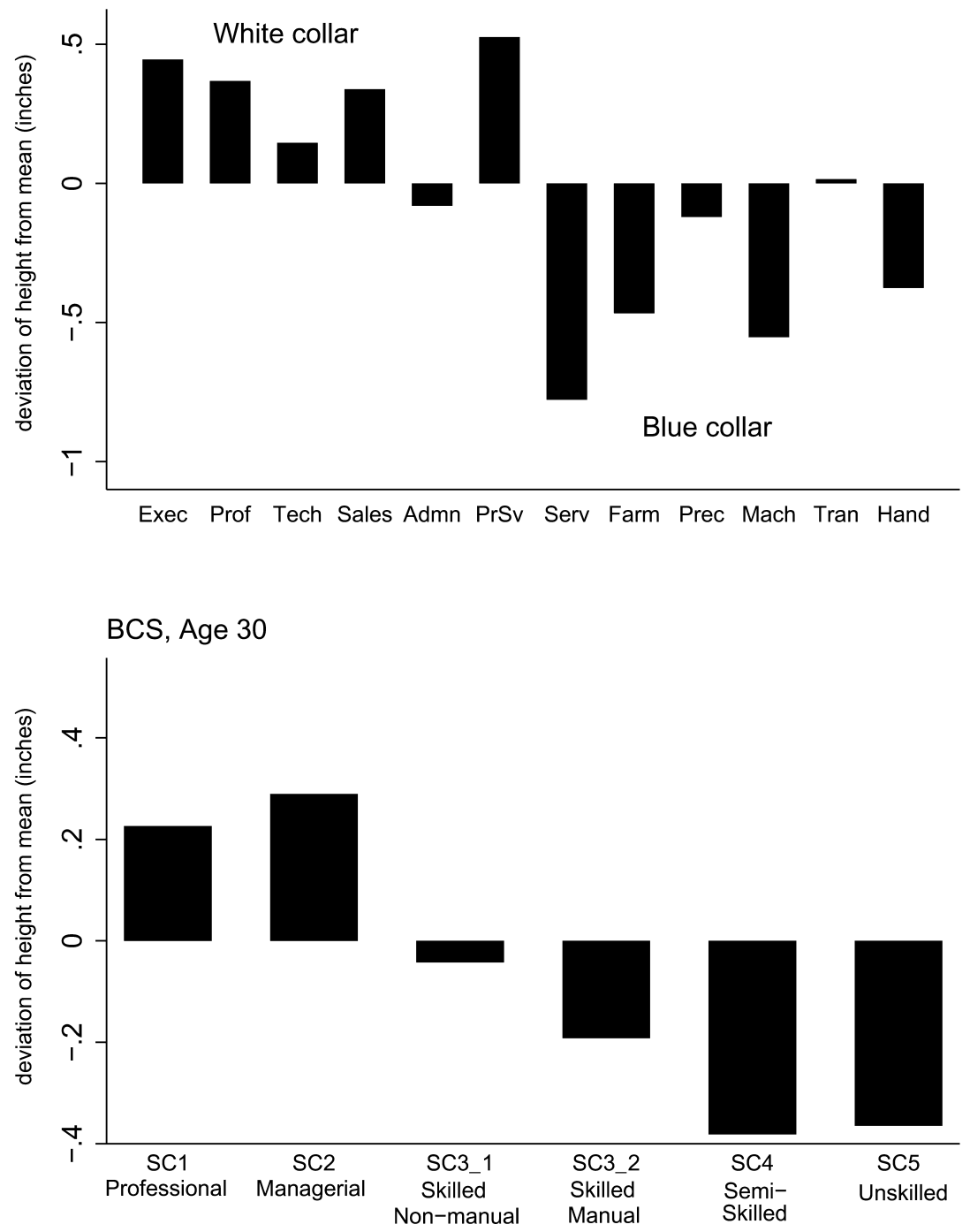

FIG. 1.-Heights across occupations, men. U.S. evidence is based on data from the National Health Interview Survey, and British evidence is based on data from the 1970 British Cohort Study. 
TABLE 1

Log Earnings and Height

\begin{tabular}{|c|c|c|c|c|}
\hline \multirow[b]{2}{*}{ DEPENDENT VARIABLE } & \multicolumn{2}{|c|}{ MEN } & \multicolumn{2}{|c|}{ WOMEN } \\
\hline & $\begin{array}{c}\text { Height } \\
\text { Coefficient }\end{array}$ & Observations & $\begin{array}{c}\text { Height } \\
\text { Coefficient }\end{array}$ & Observations \\
\hline & \multicolumn{4}{|c|}{ A. NCDS } \\
\hline $\begin{array}{l}\text { Log weekly gross } \\
\text { earnings }\end{array}$ & $\begin{array}{c}.026 \\
(.004)\end{array}$ & 4,927 & $\begin{array}{c}.024 \\
(.007)\end{array}$ & 5,033 \\
\hline \multirow[t]{2}{*}{$\begin{array}{l}\text { Log average hourly } \\
\text { gross earnings }\end{array}$} & $\begin{array}{l}.023 \\
(.004)\end{array}$ & 4,860 & $\begin{array}{l}.019 \\
(.005)\end{array}$ & 4,995 \\
\hline & \multicolumn{4}{|c|}{ B. BCS } \\
\hline $\begin{array}{l}\text { Log weekly gross } \\
\text { earnings }\end{array}$ & $\begin{array}{l}.014 \\
(.003)\end{array}$ & 2,265 & $\begin{array}{l}.029 \\
(.006)\end{array}$ & 2,136 \\
\hline \multirow[t]{2}{*}{$\begin{array}{l}\text { Log average hourly } \\
\text { gross earnings }\end{array}$} & $\begin{array}{l}.010 \\
(.003)\end{array}$ & 2,253 & $\begin{array}{l}.015 \\
(.004)\end{array}$ & 2,127 \\
\hline & \multicolumn{4}{|c|}{ C. PSID } \\
\hline Log weekly earnings & $\begin{array}{l}.023 \\
(.004)\end{array}$ & 23,465 & $\begin{array}{l}.014 \\
(.006)\end{array}$ & 21,271 \\
\hline $\begin{array}{l}\text { Log average hourly } \\
\text { earnings }\end{array}$ & $\begin{array}{l}.019 \\
(.004)\end{array}$ & 23,465 & $\begin{array}{l}.012 \\
(.003)\end{array}$ & 21,271 \\
\hline $\begin{array}{l}\text { NotE.-Ordinary least squa } \\
\text { parentheses. The NCDS and } \\
\text { at the individual level. The N } \\
11 \text { (NCDS) or } 5 \text { and } 10 \text { (BCS } \\
\text { and } 60 \text {, inclusive, between } 19\end{array}$ & $\begin{array}{l}\text { S) regression } \\
\text { ressions use } n \\
\text { BCS samples } \\
\text { SID sample cc } \\
\text { 997. NCDS an }\end{array}$ & $\begin{array}{l}\text { ients reported for } \\
\text { e observations pe } \\
\text { stricted to those f } \\
\text { of white househ }\end{array}$ & $\begin{array}{l}\text { sht in inches, } \\
\text { son, and unol } \\
\text { oom we have t } \\
\text { eads or wives }\end{array}$ & $\begin{array}{l}\text { standard errors in } \\
\text { ables are clustered } \\
\text { cores at ages } 7 \text { and } \\
\text { een the ages of } 25 \\
\text { ity, and the NCDS } \\
\text { ators. }\end{array}$ \\
\hline
\end{tabular}

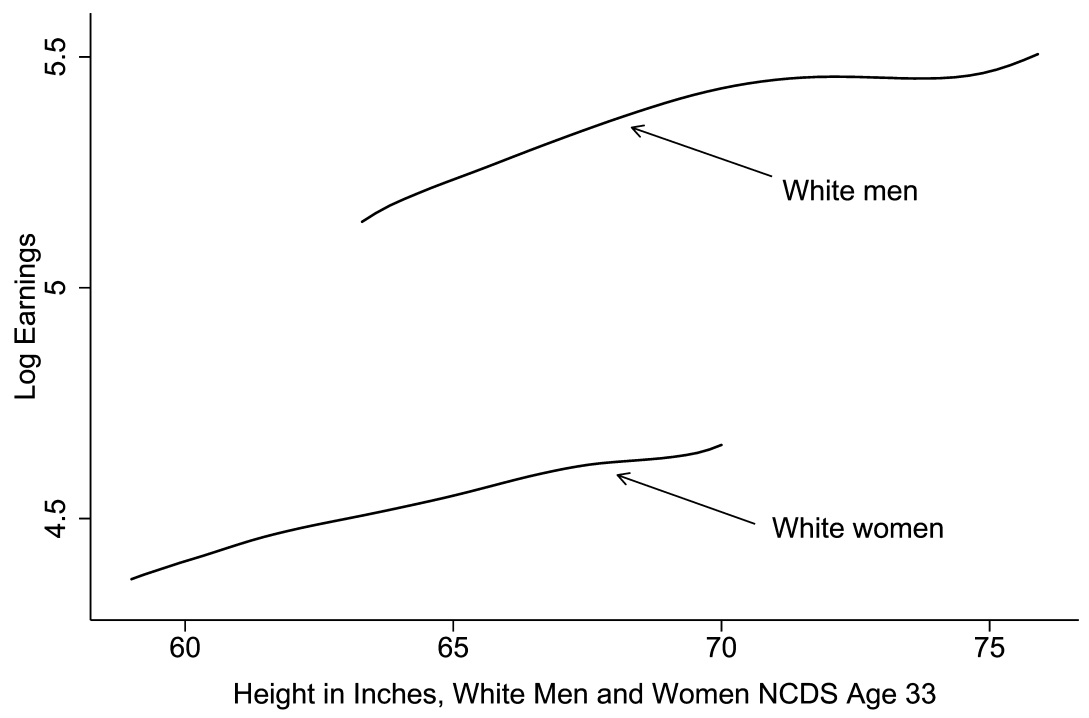

FIG. 2.-Log earnings and height, men and women 
during adolescence are more likely to participate in social activities that build productive human capital. They postulate that adolescent experiences are responsible for the higher earnings observed for taller men in adulthood, so that those who are short as teenagers have lower earnings, even if their heights "catch up" by adulthood.

In this paper, we offer a simpler explanation: the height premium in earnings is largely due to the positive association between height and cognitive ability, and it is cognitive ability rather than height that is rewarded in the labor market. As early as age 3-before schooling has had a chance to play a role-and throughout childhood, taller children perform significantly better on cognitive tests. The correlation between height in childhood and adulthood is approximately 0.7 for both men and women, so that tall children are much more likely to become tall adults. As adults, taller individuals are more likely to earn more, not because of their heights per se, but because of the cognitive skills with which height is correlated.

Section II reviews the literature on the environmental and genetic determinants of growth and cognition and discusses the reasons why height and cognitive ability are likely to be correlated. This review underscores the fact that not only are more advantaged children taller on average as adults, they also experience earlier adolescent growth spurts than less advantaged children. Section III contains a theoretical framework that is consistent with the facts we lay out and motivates our empirical research. Section IV discusses the data sets we use, and Section $\mathrm{V}$ presents evidence. We first use four data sets-two from the United States and two from the United Kingdom-to document the associations between heights and cognitive test scores in childhood. We then use data from two British birth cohort studies to show that, when measures of cognitive ability in childhood are included in earnings regressions such as those presented in table 1 , the associations between hourly earnings and adult height fall by half. Finally, we take up the issue of adult earnings and the timing of growth during childhood. We show that, consistent with our theoretical framework, cognitive ability in childhood is associated with the timing of the adolescent growth spurt for both boys and girls, and that test scores measuring cognitive function in childhood can explain much of the association found between height at various ages and earnings in adulthood.

\section{Background on Height, Growth, and Cognition}

The Determinants of Height and Growth

Adult height reflects cumulative growth up to maturity. Figure 3 graphs the speed of growth (often referred to as growth velocity in the auxology 


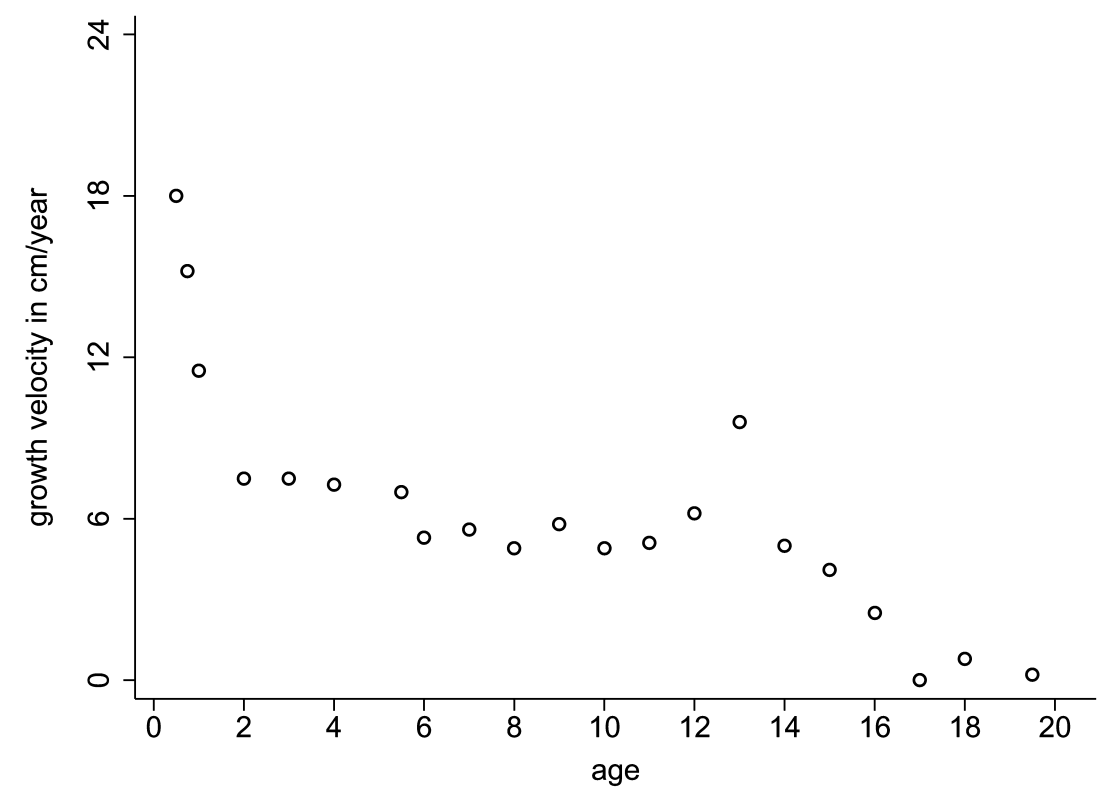

FIG. 3.-Growth velocity for boys in the United States, centimeters per year. Data were reported by the Centers for Disease Control (1977) and are drawn from direct measurement of national samples of the U.S. civilian, noninstitutionalized population.

literature) in centimeters per year against age and depicts the usual pattern of growth observed in wealthy countries. After a period of intense growth from ages 0 to 3 , growth becomes relatively stable at approximately 6 centimeters a year until adolescence, at which point an adolescent growth spurt accelerates growth to an (adolescent) peak height velocity of approximately 10 centimeters a year. In current European cohorts, girls tend to reach peak height velocity at age 12 and boys at age 14. Final adult height is attained when growth ceases, which depends on the timing and duration of the adolescent growth spurt. (See Beard and Blaser [2002] for a thorough discussion and references.)

Age-specific growth patterns and final adult height depend on a combination of factors, including genes, environmental conditions, and gene-environment interactions. A recent review of the literature concludes that, in Western countries, approximately 80 percent of variation in body height is genetic and 20 percent is due to environmental factors (Silventoinen 2003). Little is known about gene-environment interactions in height. Although environmental factors explain a relatively small share of the variation in height, they appear to account for most of the differences in average heights across populations (Steckel 1995). The marked increase in heights observed throughout the developed world 
during the twentieth century occurred too rapidly to be due to selection and genetic variation (Beard and Blaser 2002).

The most important environmental factors influencing height are thought to be the quality of the uterine environment and, in childhood, nutritional status and the disease environment. The uterine environment is itself influenced by a variety of factors, including the mother's nutritional intake and health (in particular, vascular disease), maternal smoking and drug use, and fetal infections (Institute of Medicine 2001; Resnik 2002). Low birth weight, which is one measure of the quality of the uterine environment, has been shown to be a significant predictor of lower adult stature in a number of industrialized countries (see, e.g., Ericson and Kallen 1998; Hack et al. 2003). The association between birth weight and adult height has been found within monozygotic twin pairs, suggesting that nutrition in utero is an important determinant of adult height (Behrman and Rosenzweig 2004; Black, Devereux, and Salvanes 2007).

Adult height is also sensitive to environmental conditions experienced in childhood. The period from birth to age 3 is generally identified as the postnatal period most critical to adult height. The speed of growth is more rapid during this period than at any other during the life course, and nutritional needs are greatest at this point. Infections (especially gastrointestinal and respiratory) can be frequent and severe in early childhood, and they can impair growth. In addition, children are at special risk from poor care giving at youngest ages; once children are more autonomous, they may be better equipped to protect themselves. (See Martorell, Khan, and Schroeder [1994] for a discussion.)

Environmental conditions in childhood also affect the timing of children's growth. The age of onset of the adolescent growth spurt has fallen over the past two centuries, in step with a fall in age at maturation. In late nineteenth-century Europe, adult height was attained at age 26substantially different from today's estimates of age 18 for boys and age 16 for girls (Beard and Blaser 2002). The timing of the adolescent growth spurt and age at maturation also vary cross-sectionally. Through a combination of better nutrition and improved disease environments, children of higher socioeconomic status experience an earlier adolescent growth spurt and attain their adult heights at earlier ages. ${ }^{1}$ Children

\footnotetext{
${ }^{1}$ In related work, Eveleth and Tanner $(1990,169)$ note that "amongst almost all populations for which we have data the well-off girls reach menarche earlier than the poorlyoff." On the face of it, this would seem to contradict the fact that, in the United States, African American girls reach puberty earlier on average than Caucasian girls of European descent (Eveleth and Tanner 1990; Herman-Giddens et al. 1997; Sun et al. 2002). However, if, as Eveleth and Tanner suggest, there are genetic causes for differences across populations in age at menarche, one would need to look at differences across socioeconomic status within race to evaluate their statement. Recent research has highlighted differences in serum leptin concentrations and insulin-like growth factor concentrations between races
} 
who experience deprivation may experience an extension of the growth period that can last several years (Steckel 1995). An extended adolescent growth spurt can help shorter children gain a similar amount of height as other children do during adolescence, but on average this does not erase height deficits that developed in early childhood (Satyanarayana et al. 1989; Martorell, Rivera, and Kaplowitz 1990; Martorell et al. 1994; Hack et al. 2003).

Differences in the timing of pubertal growth spurts act to temporarily magnify differences in heights between economic classes during adolescence. This has long been true: data collected at a boarding school in Germany in the eighteenth century, for example, suggest that upperclass boys reached their peak height velocity a full year earlier than lower-class boys, exaggerating the height difference between them during their teen years (Komlos et al. 1992). When the authors control for year and region of birth, height differences between sons of low aristocrats and middle-class boys grew from 2.4 centimeters at age 10 to 5.8 centimeters at age 15 , before returning to a mean height difference of 2.1 centimeters at age 19 .

\section{Height and Cognitive Ability}

The positive association between height and IQ has been documented in studies going back at least a century (Tanner 1979). However, the mechanisms that underlie this relationship are still not well understood. The existing evidence on channels linking height and cognitive ability comes from medical research; sibling and twin studies; studies of shocks to the early-life environment, which offer the possibility of examining outcomes through the lens of natural experiments; and observational studies.

Biological channels have been identified that may influence both height and cognition over a broad range of the population. ${ }^{2}$ Insulinlike growth factors affect body growth while also influencing areas of the brain in which cognition occurs (Berger 2001). Similarly, thyroid hormone stimulates growth and at the same time influences neural development (Richards et al. 2002). It is unclear, however, precisely how genetic and environmental factors interact in operating these biological channels. ${ }^{3}$

as possible reasons for earlier menarche among African Americans (Wong et al. 1998, 1999).

${ }^{2}$ Several rare genetic disorders also result in both short stature and cognitive impairment. Turner's syndrome, e.g., is an X-linked genetic disorder that affects stature and some aspects of cognitive development in girls.

${ }^{3}$ See Brown and Demmer (2002) for a discussion of the role of gene-environment interactions in the context of congenital hypothyroidism. 
Evidence on the role of genetics in explaining the correlation between height and intelligence comes from a number of twin studies. Sundet et al. (2005) use differences in cross-trait (height and intelligence), cross-twin correlations between monozygotic (MZ) and dizygotic (DZ) twin pairs to identify the roles played by shared environments and shared genes. They conclude that the environment plays a large role and is responsible for 65 percent of the height-intelligence correlation, with genes responsible for 35 percent of the observed correlation. These authors report that their results are very similar to those on cross-trait, cross-twin correlations found much earlier by Husén (1959) in a large study of MZ and DZ twin pairs.

Twin studies also shed light on the role played by nutrition in utero as a determinant of both adult height and IQ. Black et al. (2007) examine data on male twin pairs born in Norway between 1967 and 1987, noting that the difference in the twins' birth weights is largely due to nutritional intake in utero. They find that, on average, the twin born at the higher birth weight is significantly taller in adulthood and scores significantly higher on IQ tests. Similarly, using data from the Minnesota Twin Registry and an MZ fixed-effect framework, Behrman and Rosenzweig (2004) find fetal growth (birth weight divided by gestation) to be significantly associated with height and years of completed schooling in adulthood.

Almond (2006) uses the arrival of the 1918 influenza pandemic as a natural experiment with which to gauge the long-run consequences of prenatal exposure to the flu. He finds that individuals who were exposed during gestation had lower educational attainment and poorer health in adulthood than individuals born prior to the outbreak or conceived after the pandemic ended. ${ }^{4}$

Nutrition in infancy and childhood may also affect cognitive ability as well as height, producing a correlation between the two (Lynn 1989; Kretchmer, Beard, and Carlson 1996). Several randomized experiments support this idea. One found that nutritional supplements given to growth-retarded children improved their cognitive test scores, although these gains dissipated after the supplementation ended (GranthamMcGregor 2002). A follow-up to the Guatemalan INCAP (Instituto de Nutrición de Centroamérica y Panama) study, which provided children

\footnotetext{
${ }^{4}$ Although Almond does not assess height or cognitive function, his findings for educational attainment and health in adulthood suggest that the channel from prenatal health to adult outcomes may provide another link between height and cognition. A related link may occur through inflammation. Crimmins and Finch (2006) argue that an inflammatory response to infection can inhibit growth. In particular, they note that "if infection occurs during development, substantial energy is reallocated at the expense of growth, as required by the body for immune defense reactions and for repair" (500). Inflammation is also thought to have lasting effects on cognitive function (Holding and Snow 2001; Ekdahl et al. 2003).
} 
with nutrition supplements, found long-term effects on the heights of children who received the treatment during the first 3 years of life and gains in (some) cognitive test scores and educational attainment (Martorell et al. 2005). Although these studies are intriguing, it should be noted that both were conducted in very impoverished environments. There is little direct evidence on how childhood nutrition influences cognitive development in wealthier settings.

Observational studies suggest that an additional link between height and cognition may work through maternal smoking during pregnancy, which is associated with slower fetal growth, as well as lower cognitive test scores, behavioral problems, and attention deficit hyperactivity disorder (Weitzman, Gortmaker, and Sobol 1992; Romano et al. 2006). While these outcomes may be the result of factors correlated with mother's smoking during pregnancy rather than the direct effect of smoking, animal studies have documented the role of prenatal nicotine exposure on neural development (Slotkin 1998).

\section{Empirical Framework}

We develop a statistical model in which both cognitive ability and height at different ages are influenced by an unobserved factor that reflects the combined effects of environmental conditions (such as health and nutrition), biological factors, genetic factors, and gene-environment interactions. We refer to the unobserved factor as an individual's endowment. For our purposes, it is not necessary to distinguish the genetic and environmental factors that determine this endowment. ${ }^{5}$ To the extent that they reflect genetic inheritance, or gene-environment interactions in utero, endowments would be fixed at birth. However, as discussed above, early-life environment is also critical to physical and cognitive development, and the only assumption we need in order to keep the model simple is that endowments are set prior to the childhood measurements we have for height and cognitive function.

We use the model to derive testable implications for the relationships between wages, cognitive ability, and heights in both childhood and adulthood. We assume that cognitive ability $c$ is a linear function of the endowment $n$. Assuming that all variables have been centered around their means, we have

$$
c=\lambda n+u,
$$

where $n$ is defined so that $\lambda$ is positive. Heights at each age, from

\footnotetext{
${ }^{5}$ Understanding the extent to which this endowment can be influenced by prenatal care and early-life environment is of great importance for social policy. Unfortunately, we do not currently have access to data that would allow us to address this.
} 
childhood to early adulthood, are also assumed to be linear functions of the endowment. After heights at each age are centered around their means, height at age $i$ is expressed as

$$
h_{i}=a_{i} n+v_{i}, \quad i=1, \ldots, K,
$$

where $h_{K}$ refers to final adult height. Although we expect $a_{i}$ to be positive for each age, this parameter is not necessarily the same for all ages. The literature discussed above indicates that $a_{i}$ may be larger during the years of the adolescent growth spurt than in middle childhood or in adulthood. It may also be large in early childhood, when height reflects prenatal conditions and early childhood health and nutrition.

For simplicity, we assume that the wage in adulthood is a function of cognitive ability alone and is not a function of height:

$$
w=\beta c+e .
$$

We also assume that the unobserved endowment is the only factor that produces correlations between cognitive ability, heights, and wages, so that the covariances between all error terms in (1), (2), and (3) are zero. The variance of $v_{i}$ is denoted as $\sigma_{i}^{2}$ and the variance of $n$ is $\sigma_{n}^{2}$.

Given this framework, a regression of the wage on height at any single age will yield a positive coefficient. Specifically, the coefficient on $h_{i}$, when it is the only height measure included in the wage regression, will have a probability limit of

$$
p \lim b_{i}=\beta \lambda a_{i}\left[\frac{1}{a_{i}^{2}+\left(\sigma_{i}^{2} / \sigma_{n}^{2}\right)}\right] .
$$

In words, the coefficient on height in the wage regression reflects the association between height and cognitive ability that works through the unobserved endowment $n$. It declines as the error variance in height increases relative to the variance of the endowment, making height a noisier signal of cognitive ability.

When the wage is regressed on multiple height measures from different ages, the coefficients on heights will be proportional to the $a_{i}^{\text {'s }}$ that relate the endowment to heights. Specifically, if the wage is regressed on height measures $1, \ldots, K$, the probability limit of any single parameter estimate is

$$
p \lim b_{i}=\beta \lambda\left(\frac{1}{1+\sigma_{n}^{2} S_{a}}\right) \frac{a_{i} \sigma_{n}^{2}}{\sigma_{i}^{2}},
$$

where

$$
S_{a}=\sum_{i=1}^{K}\left(\frac{a_{i}}{\sigma_{i}}\right)^{2} .
$$


Equation (5) implies that, provided the error variances $\left(\sigma_{i}^{2}\right)$ are constant across ages, the height measure that has the largest association with the endowment will have the largest coefficient in the wage regression. If heights measured early in childhood and during the adolescent growth spurt have the largest associations with the endowment, then so too will heights at these ages have the largest associations with wages. A related implication is that the associations between height at different ages and the wages of men and women will differ, since boys and girls go through their adolescent growth spurts at different ages. We examine these implications in the empirical work that follows.

Two caveats require discussion. The first is that the results discussed above can be overturned if the error variances in heights differ across age groups. For example, if the variance of height, conditional on $n$, rises with age, then heights measured earlier in childhood may take larger coefficients than those measured in later childhood or adulthood. We know of no biological reason why the variances in heights, conditional on endowments, would be greater at some ages than at others. However, there may be age-specific variation in measurement error in heights, especially for parent-reported heights of (rapidly growing) children. Our empirical work relies mainly on heights that are measured during doctor visits, reducing the possibility of age-specific measurement error.

A second caveat is that there may be other frameworks that yield similar conclusions regarding estimates of the associations between heights at different ages and wages. For example, Persico et al. (2004) use data from the NCDS to show that, for men, height at age 16 takes a larger coefficient in a wage regression than height in adulthood. They do not interpret this as reflecting the effects of the endowment on the timing of the adolescent growth spurt, but instead argue that boys who are tall in adolescence (conditional on adult height) are more likely to participate in social activities that build productive human capital, resulting in higher earnings later in life. It could also be that taller adolescents are treated differently by parents or teachers, in ways that build human capital.

It is possible to distinguish between the model developed above and these alternatives, given measures of cognitive ability in childhood. One testable implication of our framework is that if the association between height and the wage reflects only unobserved cognitive ability, then the coefficients on heights in wage regressions should go to zero when adequate measures of cognitive ability are included in the regression. This will be the case regardless of whether a single height measure or multiple measures of height are included. Another testable implication of our framework is that cognitive ability in childhood should predict the timing of the adolescent growth spurt: children who have higher 
cognitive test scores should experience the adolescent growth spurt at younger ages. Neither of these results is an implication of alternatives in which height is a direct contributor, in adolescence or adulthood, to human capital.

\section{Data}

We use four well-known data sets that bring different strengths to the analysis. Documenting the chain from height and ability in childhood to earnings in adulthood requires panel data that include measures of heights from childhood to adulthood, childhood cognitive ability, and adult labor market outcomes. Two publicly available British birth cohort studies-the 1958 National Child Development Study and the 1970 British Cohort Study-fulfill these criteria. The NCDS has followed all children born in England, Scotland, and Wales in the week of March 3, 1958, from birth to age 42. Follow-up surveys on health and economic well-being were conducted at ages $7,11,16,23,33$, and 42. In similar fashion, the BCS has followed all individuals living in Great Britain born in the week of April 5, 1970. Follow-up surveys were conducted at ages $5,10,16,26$, and 30 .

Both the NCDS and the BCS administered cognitive tests to cohort members at early ages ( 7 and 11 in the NCDS, 5 and 10 in the BCS), and both surveys report earnings in adulthood (at ages 33 and 42 in the NCDS and at age 30 in the BCS). Children's heights were measured at each age during medical exams. However, two-thirds of the BCS sample has missing height information at age 16; we use only the NCDS when we examine adolescent heights. For NCDS cohort members, we draw our adult height measure from the medical exam data collected at age 33. The BCS cohort members were not given medical exams in adulthood; for this birth cohort, we use self-reported height at age 30 .

The British birth cohort studies are rich in the information they report from birth through middle age. However, because they follow only cohort members (and not, e.g., their siblings) and because childhood measurements start only at age 5 or 7 , we augment our analysis with data from two additional data sets, chosen to document particular pieces of the association between cognitive test scores and height in childhood. For data on siblings, we draw on the 1979 National Longitudinal Study of Youth (NLSY79) Child and Young Adults surveys, conducted in even years from 1986 to 2004, which collected information on the children of women in the original NLSY79 sample. We use the NLSY data to examine whether and how differences in test scores across siblings are related to differences in their heights. For test scores on very young children, we draw on the Fragile Families and Child Wellbeing Study, a U.S. birth cohort study of urban children who were born around the 
TABLE 2

SumMary Statistics

\begin{tabular}{lcc}
\hline \hline & NCDS & BCS \\
\hline Observations & 9,155 & 9,003 \\
Ethnicity European/Caucasian & .990 & .976 \\
Female & .508 & .514 \\
Adult height (inches): & 64.15 & 64.16 \\
$\quad$ Women & 69.65 & 69.72 \\
$\quad$ Men & .187 & .171 \\
Indicator: father professional, manager & .613 & .588 \\
Indicator: father skilled worker & & \\
Average hourly gross earnings: & 10.22 & 7.94 \\
$\quad$ Women (age 42 NCDS, age 30 BCS) & 14.18 & 9.45 \\
$\quad$ Men (age 42 NCDS, age 30 BCS) & .800 & .742 \\
Full/part-time employment: & .921 & .901 \\
$\quad$ Women (age 42 NCDS, age 30 BCS) & & .901 \\
$\quad$ Men (age 42 NCDS, age 30 BCS) & & \\
\hline NoTE.-The NCDS cohort is restricted to individuals with height measured at ages 7 and 33. The BCS cohort is \\
restricted to individuals with height measured at ages 5 and 30. Earnings are reported only for cohort members who \\
report full- or part-time employment.
\end{tabular}

beginning of the twenty-first century (Reichman et al. 2001), which tested children's vocabularies at age 3. Although the Fragile Families study contains information on only one child per household, it has the advantage of having information on heights and test scores for a large number of children before they reach school-going age.

Summary statistics for the British cohort studies are presented in table 2 , where we restrict our attention to cohort members who were present in childhood and again in adulthood (ages 7 and 33 for the NCDS, ages 5 and 30 for the BCS). Almost all members of both cohort studies are of European Caucasian descent. Men in both studies stand 5 feet 10 inches tall on average in adulthood and women 5 feet 4 inches. Twenty percent of cohort members were born to fathers in the two highest occupational classes (professionals, executives, and managers) and 60 percent to fathers in the next two classes (nonmanual and manual skilled workers). Approximately 90 percent of men in both cohorts report working full- or part-time; this is true for 80 percent of women in the NCDS at age 42 and 74 percent of women in the BCS at age $30 .^{6}$

\section{Results}

Height and Growth in the NCDS Cohort

The growth literature suggests that children raised in healthier environments will be taller in childhood and experience earlier adolescent

\footnotetext{
${ }^{6}$ The lower rate of labor force participation among women should be kept in mind when interpreting our results. Factors that influence women's selection into the labor force could be correlated with height and cognitive ability.
} 
TABLE 3

Heights by Father's Occupational Grade and Age: NCDS

\begin{tabular}{|c|c|c|}
\hline & $\begin{array}{c}\text { Men } \\
(1)\end{array}$ & $\begin{array}{l}\text { Women } \\
\quad(2)\end{array}$ \\
\hline Father's occupational grade is medium & $\begin{array}{r}-.608 \\
(.071)\end{array}$ & $\begin{array}{r}-.685 \\
(.076)\end{array}$ \\
\hline Father's occupational grade is medium $\times$ age 11 & $\begin{array}{r}-.108 \\
(.068)\end{array}$ & $\begin{array}{r}-.094 \\
(.075)\end{array}$ \\
\hline Father's occupational grade is medium $\times$ age 16 & $\begin{array}{r}-.299 \\
(.093)\end{array}$ & $\begin{array}{r}-.048 \\
(.075)\end{array}$ \\
\hline Father's occupational grade is medium $\times$ age 33 & $\begin{array}{r}-.017 \\
(.088)\end{array}$ & $\begin{array}{l}.046 \\
(.080)\end{array}$ \\
\hline Father's occupational grade is low & $\begin{array}{r}-1.011 \\
(.087)\end{array}$ & $\begin{array}{r}-.914 \\
(.092)\end{array}$ \\
\hline Father's occupational grade is low $\times$ age 11 & $\begin{array}{r}-.228 \\
(.083)\end{array}$ & $\begin{array}{l}-.214 \\
(.091)\end{array}$ \\
\hline Father's occupational grade is low $\times$ age 16 & $\begin{array}{c}-.466 \\
(.117)\end{array}$ & $\begin{array}{c}-.200 \\
(.093)\end{array}$ \\
\hline Father's occupational grade is low $\times$ age 33 & $\begin{array}{l}.180 \\
(.108)\end{array}$ & $\begin{array}{c}-.127 \\
(.098)\end{array}$ \\
\hline \multicolumn{3}{|l|}{ Hypothesis tests ( $p$-values reported): } \\
\hline $\begin{array}{l}\text { No significant difference in age patterns between high } \\
\text { and medium }\end{array}$ & .009 & .352 \\
\hline $\begin{array}{l}\text { No significant difference in age patterns between high } \\
\text { and low }\end{array}$ & .000 & .045 \\
\hline $\begin{array}{l}\text { No difference in height deficit at ages } 16 \text { and } 33 \text {, } \\
\text { medium }\end{array}$ & .005 & .190 \\
\hline $\begin{array}{l}\text { No difference in height deficit at ages } 11 \text { and } 33 \text {, } \\
\text { medium }\end{array}$ & .324 & .146 \\
\hline No difference in height deficit at ages 16 and 33 , low & .000 & .427 \\
\hline No difference in height deficit at ages 11 and 33, low & .000 & .458 \\
\hline Observations & 22,387 & 21,607 \\
\hline
\end{tabular}

NotE.-These regressions are based on a data set in which there is one observation per respondent for each round of the NCDS (in which the respondent participated). Height is measured in inches. Father's occupational grade is defined as "high" if the child's father had a professional, managerial, or technical occupation at the time of the child's birth; as "medium" if the father was a skilled worker at the time of the child's birth; and "low" if the father was a semiskilled or unskilled worker at the time of the child's birth. (Mother's occupation is used if the father's occupation is not listed.) The regressions include a set of indicators for the child's ethnicity and a set of indicators for the month of age at measurement. For observations at age 33, all individuals are assigned the same month of measurement indicator. Standard errors are clustered at the level of the individual.

growth spurts. We observe these patterns in the 1958 NCDS cohort. Table 3 reports the results of regressions of heights in childhood and adulthood on the child's father's occupation grade, classified as "low" if the father was an unskilled or semiskilled worker, "medium" if he was a skilled worker, and "high" if he was in a professional, managerial, or technical occupation. Cohort members' heights (in inches) are measured at ages $7,11,16$, and 33 . The data are arranged so that there is one observation per individual at each age of measurement. Heights are regressed on indicators of the age of measurement, indicators of the father's occupational grade, and interactions between the age of measurement and father's occupational grade, with age 7 being the excluded age category in these interactions. The standard errors are clustered at the level of the individual. 
Consider, first, the results for men in column 1. They indicate that, at age 7 , boys whose fathers were in the medium grade were 0.61 inch shorter on average than boys whose fathers were in the highest grade; boys whose fathers were in the lowest grade were 1.01 inches shorter on average than those whose fathers were in the highest grade. These differences in average heights across grades become larger as children grow older, taking their largest values at age 16 . The average height deficit of boys with low-grade relative to high-grade fathers rises from 1.01 inches at age 7 , to 1.24 inches $(-1.01-0.23)$ at age 11 , and to 1.48 inches at age 16. This gap diminishes somewhat in adulthood, as lower-class boys experience some "catch-up" in height. Test statistics presented at the bottom of the table show that, for boys whose fathers were unskilled or semiskilled, height deficits at ages 11 and 16 are significantly larger than the height deficit at age $33 .^{7}$

The gap in height between boys whose fathers were in the highest grade and those in the medium grade is the same at age 33 as it was at age 7 ; the interaction term for being in the medium group and being age 33 is small and statistically insignificant, suggesting that those boys grew more between 16 and 33 than boys in the high grade, in order to return to the gap they faced at age 7 . The same is true for boys in the low grade, who picked up 0.67 inch of height relative to high-grade boys between age 16 (when they were an additional 0.47 inch shorter than high-grade boys than they had been at age 7) and age 33 (when their height deficit has fallen to below the level it had been at age 7 by 0.18 inch).

The results for women are somewhat different. At age 7, girls whose fathers were in professional occupations are 0.7 inch taller on average than girls whose fathers were skilled workers and 0.9 inch taller than girls whose fathers were semi- or unskilled workers. The point estimates indicate that the differences in average heights between women with low-grade and medium-grade fathers, relative to those with high-grade fathers, reach their largest values at age $11 \quad(-0.914-0.214=$ -1.128 for girls in the lowest category at age 11). However, the deficits at ages 11 and 16 are similar to each other and are not significantly different from their values at age 33. The difference in results between men and women may be due to the earlier adolescent growth spurt experienced by girls and the timing of the NCDS surveys. Girls' peak height velocity occurs, on average, closer to the age 11 survey than to the age 16 survey. Nearly all girls will have completed their adolescent growth spurts by age 16 , which is not true for boys. While we find

\footnotetext{
${ }^{7}$ That children in the NCDS from poorer backgrounds have "a delayed pattern of growth before the pubertal spurt, followed by catch-up growth" has been noted earlier by $\mathrm{Li}$, Manor, and Power $(2004,185)$.
} 
significant differences in the growth patterns of girls from higher-status and lower-status backgrounds, in the absence of information on heights at each age in adolescence, it is not possible to tell whether the differences in average heights between girls from more and less advantaged backgrounds become more pronounced during the period of peak height velocity.

These results have several implications for the analysis of the relationship between earnings and heights at different ages. First, they indicate that heights in both childhood and adulthood are associated with the economic status of a child's family. As discussed above, this association may reflect a combination of genetic and environmental factors that also drive productivity in the labor market. A second implication is that growth patterns throughout childhood may convey more information about endowments than heights in adulthood alone. For boys, especially, height at age 16 may be a good marker for unobserved ability. We return to this below when we examine the relationship between earnings and heights at different ages in childhood.

\section{Height and Childhood Cognitive Test Scores}

We present direct evidence on the relationship between height and test scores in childhood in table 4, using data from the NCDS and the BCS. The tests administered to children vary across ages and surveys. For the 5 -year-olds in the BCS, we show results for a human figure drawing score, which provides a measure of conceptual maturity; a copy design test that measures visual-motor coordination; and the English Picture Vocabulary Test (EPVT) score, which measures the size of the child's vocabulary. At age 10, we show results for the four subscales of the British Ability Scales (BAS) included in the BCS. We chose to report these rather than scores on the math, reading, and vocabulary tests that were given at age 10, since the BAS subscales are meant to measure cognitive ability rather than academic achievement. ${ }^{8}$ For the NCDS, we show results for the human figure drawing test and math and reading scores

\footnotetext{
${ }^{8}$ That said, regression results for standardized vocabulary and math tests are very similar to those for the BAS test scores at age 10. Each inch of height is associated with approximately a 10 percent of a standard deviation increase in the Pictorial Language Comprehension Test and in the Friendly Maths Test in the absence of extended controls. The coefficient on the height for age $5 z$-score for the verbal test is 0.111 (standard error $0.009)$ and for the math test is $0.121(0.010)$. Similarly to the BAS results, with extended controls, these coefficients fall by half, to $0.046(0.010)$ for the vocabulary test and to $0.054(0.010)$ for the math test. Results for the Edinburgh Reading Test are less pronounced, with a coefficient on height taking a value of $0.047(0.010)$ in the absence of extended controls and $0.008(0.011)$ in their presence. These results do not support a model in which taller children are spurred on by teachers or the social setting of the classroom to outperform shorter peers. If they were, we would expect larger height effects for tests of academic achievement than for cognitive ability.
} 
TABLE 4

Test Scores and Height in Childhood: NCDS and BCS

\begin{tabular}{|c|c|c|c|c|}
\hline \multirow[b]{2}{*}{ Dependent Variable } & \multicolumn{3}{|c|}{$\begin{array}{l}\text { CONTROLS FOR SEX, } \\
\text { ETHNICITY, AND AGE }\end{array}$} & \multirow{2}{*}{$\begin{array}{c}\text { EXTENDED } \\
\text { CONTROLS: } \\
\text { BOYS AND } \\
\text { GIRLS } \\
(4)\end{array}$} \\
\hline & $\begin{array}{l}\text { Boys and } \\
\text { Girls } \\
\text { (1) }\end{array}$ & $\begin{array}{l}\text { Boys } \\
(2)\end{array}$ & $\begin{array}{l}\text { Girls } \\
(3)\end{array}$ & \\
\hline & \multicolumn{4}{|c|}{$\begin{array}{l}\text { A. } 1970 \text { BCS Coefficient on Age } 5 \\
\text { Height for Age } z \text {-Score }\end{array}$} \\
\hline EPVT (receptive language) score at age 5 & $\begin{array}{l}.132 \\
(.008)\end{array}$ & $\begin{array}{l}.129 \\
(.012)\end{array}$ & $\begin{array}{l}.134 \\
(.012)\end{array}$ & $\begin{array}{l}.078 \\
(.009)\end{array}$ \\
\hline Human figure drawing score at age 5 & $\begin{array}{l}.070 \\
(.009)\end{array}$ & $\begin{array}{l}.057 \\
(.012)\end{array}$ & $\begin{array}{c}.083 \\
(.012)\end{array}$ & $\begin{array}{c}.041 \\
(.009)\end{array}$ \\
\hline Copy designs score at age 5 & $\begin{array}{l}.115 \\
(.008)\end{array}$ & $\begin{array}{l}.116 \\
(.012)\end{array}$ & $\begin{array}{l}.116 \\
(.012)\end{array}$ & $\begin{array}{l}.057 \\
(.009)\end{array}$ \\
\hline BAS word score at age 10 & $\begin{array}{l}.131 \\
. .010)\end{array}$ & $\begin{array}{l}.125 \\
(.014)\end{array}$ & $\begin{array}{l}.133 \\
(.013)\end{array}$ & $\begin{array}{l}.064 \\
.010)\end{array}$ \\
\hline BAS similarities score at age 10 & $\begin{array}{l}.123 \\
(.010)\end{array}$ & $\begin{array}{l}.117 \\
(.014)\end{array}$ & $\begin{array}{l}.126 \\
(.013)\end{array}$ & $\begin{array}{l}.060 \\
(.010)\end{array}$ \\
\hline BAS digit score at age 10 & $\begin{array}{l}.067 \\
(.010)\end{array}$ & $\begin{array}{l}.056 \\
(.014)\end{array}$ & $\begin{array}{l}.075 \\
(.014)\end{array}$ & $\begin{array}{l}.033 \\
(.011)\end{array}$ \\
\hline \multirow[t]{2}{*}{ BAS matrices at age 10} & $\begin{array}{l}.084 \\
(.010)\end{array}$ & $\begin{array}{l}.077 \\
(.014)\end{array}$ & $\begin{array}{l}.089 \\
(.014)\end{array}$ & $\begin{array}{l}.028 \\
(.010)\end{array}$ \\
\hline & \multicolumn{4}{|c|}{$\begin{array}{l}\text { B. } 1958 \text { NCDS Coefficient on Age } 7 \\
\text { Height for Age } z \text {-Score }\end{array}$} \\
\hline Reading score at age 7 & $\begin{array}{l}.154 \\
(.008)\end{array}$ & $\begin{array}{l}.158 \\
(.012)\end{array}$ & $\begin{array}{c}.150 \\
(.011)\end{array}$ & $\begin{array}{l}.109 \\
(.009)\end{array}$ \\
\hline Math score at age 7 & $\begin{array}{l}.123 \\
(.008)\end{array}$ & $\begin{array}{l}.124 \\
(.012)\end{array}$ & $\begin{array}{l}.121 \\
(.012)\end{array}$ & $\begin{array}{l}.081 \\
(.009)\end{array}$ \\
\hline Drawing score at age 7 & $\begin{array}{c}.112 \\
(.008)\end{array}$ & $\begin{array}{l}.111 \\
(.012)\end{array}$ & $\begin{array}{l}.111 \\
(.012)\end{array}$ & $\begin{array}{c}.076 \\
(.009)\end{array}$ \\
\hline Verbal language score at age 11 & $\begin{array}{c}.170 \\
(.009)\end{array}$ & $\begin{array}{l}.151 \\
(.013)\end{array}$ & $\begin{array}{l}.189 \\
(.012)\end{array}$ & $\begin{array}{l}.109 \\
(.009)\end{array}$ \\
\hline Nonverbal language score at age 11 & $\begin{array}{l}.179 \\
(.009)\end{array}$ & $\begin{array}{l}.175 \\
(.013)\end{array}$ & $\begin{array}{l}.184 \\
(.012)\end{array}$ & $\begin{array}{l}.117 \\
(.009)\end{array}$ \\
\hline Math score at age 11 & $\begin{array}{l}.184 \\
(.009)\end{array}$ & $\begin{array}{l}.182 \\
(.013)\end{array}$ & $\begin{array}{l}.185 \\
(.012)\end{array}$ & $\begin{array}{l}.120 \\
(.009)\end{array}$ \\
\hline Copy designs score at age 11 & $\begin{array}{c}.077 \\
(.009)\end{array}$ & $\begin{array}{l}.076 \\
(.013)\end{array}$ & $\begin{array}{l}.077 \\
(.012)\end{array}$ & $\begin{array}{c}.047 \\
(.010)\end{array}$ \\
\hline $\begin{array}{l}\text { NOTE. - Samples sizes are } 11,360 \text { for the BCS at age } 5 \\
11,232 \text { at age } 11 \text {. All regressions control for the age of the } \\
\text { regressions in which boys and girls are pooled) an indi } \\
\text { also include an indicator of low birth weight, prenatal } \\
\text { for the parents' school-leaving ages, the mother's and fat } \\
\text { for family income category at age } 10 \text {. The NCDS includ } \\
\text { birth is replaced by her father's social class, and the loga } \\
\text { for income at age } 10 \text {. }\end{array}$ & $\begin{array}{l}\text { the he } \\
\text { th class } \\
\text { ne exte }\end{array}$ & $\begin{array}{l}\text { Seach } \\
\text { each } \\
\text { ime o } \\
\text { ontro }\end{array}$ & or the & $\begin{array}{l}\text { S at age } 7 \text { and } \\
\text { cators, and (for } \\
\text { ended controls } \\
\text { ents, indicators } \\
\text { and indicators } \\
\text { s social class at } \\
\text { ce of indicators }\end{array}$ \\
\hline
\end{tabular}


at age 7 , and scores from verbal language, nonverbal language, math, and copy design tests at age 11. All tests are standardized within the sample to have a mean of zero and a standard deviation of one, and the height measures are transformed into height for age $z$-scores using the 2000 growth charts from the Centers for Disease Control (2002). This standardization makes it easier to compare estimates across ages and tests.

For both surveys, we first show results of regressions of test scores on height, controlling for only a few key variables: the child's sex, ethnicity, and the age in months at which the testing occurred. We then show results (in col. 4) that include an extended set of family background variables including the family's economic status, parent' education levels and their heights, prenatal smoking, and an indicator that the child was born at low weight. These controls, which are listed in the note to table 4 , are associated with heights in childhood and adulthood. ${ }^{9}$ We expect that the covariance between height and cognitive test scores will be smaller after conditioning on these variables, since better-off children both are taller and have higher test scores. However, approximately twothirds to three-quarters of the cross-sectional variation in heights is not explained by these variables, and it is of interest to know if the correlation between height and cognitive ability persists even after observable determinants of height are accounted for. ${ }^{10}$

We find a large and significant association between height and test scores for children followed in the BCS for tests they took at ages 5 and 10 (panel A) and for children in the NCDS for tests at ages 7 and 11 (panel B). The coefficients are somewhat larger for the NCDS, especially among 11-year-olds, but the patterns across the two cohort studies are quite similar. In neither study does it appear that the associations are

\footnotetext{
${ }^{9}$ Heights are correlated with observable factors that are likely to be determinants of cognitive development. In an earlier version of this paper, we presented results of regressions, from the NCDS, of boys' heights at different ages on measures of the child's family's socioeconomic status, including parental education and occupational-based measures of social class; measures of the child's health at birth, including low birth weight and prenatal smoking; and measures of parents' heights. All three sets of factors are significant predictors of height. Together, these variables explain between 25 and 33 percent of the variation in heights, with parental heights—which may reflect genetic factors or parents' childhood circumstances-providing the largest incremental contribution to the $R^{2}$.

${ }^{10}$ If height is capturing unobservable components of endowments, then the coefficient on height should go to zero as all unobservables are accounted for. Murphy and Topel (1990) suggest that the impact of remaining unobservables on a coefficient can be assessed by extrapolation, which, in this case, means computing the change in the coefficient on height relative to the change in the $R^{2}$ that occurs when the family background measures are included and calculating what the coefficient on height would be if the $R^{2}$ were equal to one. However, when we do this, the extrapolated coefficient on height is large and negative. The key assumption necessary for the Murphy and Topel result to hold (that the remaining unobservables are correlated with height to the same degree as the extra observables that have been added to the regression) may be unlikely to hold in our case.
} 
TABLE 5

Test Scores and Height in Childhood: Children of the NLSY and Fragile FAMiLIES

\begin{tabular}{|c|c|c|c|c|}
\hline Dependent Variable & $\begin{array}{l}\text { Limited } \\
\text { Controls } \\
\text { (1) }\end{array}$ & $\begin{array}{l}\text { Extended } \\
\text { Controls } \\
\text { (2) }\end{array}$ & $\begin{array}{c}\text { Extended } \\
\text { Controls } \\
\text { (3) }\end{array}$ & $\begin{array}{c}\text { Observations } \\
\text { (4) }\end{array}$ \\
\hline & \multicolumn{4}{|c|}{$\begin{array}{c}\text { A. Children of the NLSY, Coefficient on Age } 5-6 \\
\text { Height for Age } z \text {-Score }\end{array}$} \\
\hline PIAT mathematics & $\begin{array}{l}.067 \\
(.007)\end{array}$ & $\begin{array}{l}.052 \\
(.007)\end{array}$ & $\begin{array}{l}.031 \\
(.010)\end{array}$ & 13,834 \\
\hline PIAT reading recognition & $\begin{array}{l}.059 \\
(.007)\end{array}$ & $\begin{array}{l}.044 \\
(.007)\end{array}$ & $\begin{array}{l}.028 \\
(.010)\end{array}$ & 13,702 \\
\hline PIAT reading comprehension & $\begin{array}{l}.061 \\
(.008)\end{array}$ & $\begin{array}{l}.051 \\
(.008)\end{array}$ & $\begin{array}{l}.025 \\
(.012)\end{array}$ & 9,605 \\
\hline PPVT & $\begin{array}{l}.068 \\
(.011)\end{array}$ & $\begin{array}{l}.050 \\
(.011)\end{array}$ & $\begin{array}{l}0.027 \\
(.016)\end{array}$ & 5,227 \\
\hline \multirow[t]{2}{*}{ Digit span } & $\begin{array}{l}.056 \\
(.010)\end{array}$ & $\begin{array}{l}.048 \\
(.011)\end{array}$ & $\begin{array}{l}.018 \\
(.016)\end{array}$ & 7,042 \\
\hline & \multicolumn{4}{|c|}{$\begin{array}{l}\text { B. Fragile Families Coefficient on Age } 3 \text { Height for } \\
\text { Age } z \text {-Score }\end{array}$} \\
\hline PPVT & $\begin{array}{l}.089 \\
(.020)\end{array}$ & $\begin{array}{l}.052 \\
(.020)\end{array}$ & & 2,150 \\
\hline Mother fixed effects? & No & No & Yes & \\
\hline
\end{tabular}

Note.-Panel A shows coefficients and standard errors from OLS regressions on the Children of the NLSY, whose cognitive function was evaluated multiple times between ages 5 and 10. Each coefficient comes from a separate regression, where the reported coefficients are those on the age 5-6 height for age $z$-score. All regressions include controls for age at the time of the assessment at ages 5-6; a quartic in age at the time of each assessment; and indicators for race, sex, and year. Extended controls include an indicator for low birth weight and indicators for the number of packs of cx, altes the Exor cigarettes the Exotal ncome in the previous calendar year, indicators for the highest grade completed by the mother, and indicators that the mother's partner lives in the household and indicators that the child's maternal grandmother and grandfather live in the household. For the Fragile Families results, all regressions include indicators for gender and age in months at the time of measurement. The extended controls include an indicator for low birth weight, the heights of both parents, indicators for the educational attainment of both parents, indicators for the maternal grandfather's education, the logarithm of family income at age 3, the mother's score on the PPVT, and an indicator of whether the mother took the Spanish-language version of the PPVT (i.e., the Test de Vocabulario en Imagenes Peabody).

systematically larger for older versus younger children. The magnitudes of these associations are quite large, even when the extended controls are included. For example, in the NCDS data using extended controls, a one standard deviation increase in height at age 7 is associated with a 10 percent of a standard deviation increase in reading score at age 7 and in verbal language score at age 11. This effect is as large as that predicted by a two standard deviation increase in log household income for these children. ${ }^{11}$

Table 5 presents results from the two American data sources, the Children of the NLSY and the Fragile Families study. For the NLSY, we use scores from tests that were administered to children between the

${ }^{11}$ For reading scores at age 7 and verbal scores at age $11, \log$ family income takes a coefficient of 0.24 . A one standard deviation increase in log income is 0.234 , so that a two standard deviation increase would be necessary to have an effect as large as a one standard deviation increase in height at age 7 . 
ages of 5 and 10. The tests include the Peabody Individual Achievement Tests (PIAT) for mathematics, reading recognition, and reading comprehension, a digit span test, and the Peabody Picture Vocabulary Test (PPVT). The digit span test measures a child's short-term memory. The PPVT, on which the EPVT is based, is a test of receptive vocabulary that can be administered to individuals from age 30 months through adulthood, and it has been used in numerous studies of preschool and schoolaged children (Dunn and Dunn 1997). The PPVT was also administered to the 3-year-olds from the Fragile Families study.

For both samples, we use a set of extended controls that is comparable to those used in our analyses of the British data. One difference, however, is that both the NLSY and the Fragile Families samples contain information on the cognitive ability of mothers, in the form of an Armed Forces Qualifying Test (AFQT) score for the mothers in the NLSY and the PPVT for the mothers in the Fragile Families data. The NLSY has the additional advantage of containing information on all of the mother's children, making it possible to control for mother-specific fixed effects.

The results from the NLSY indicate that children's heights are strongly associated with test scores. The point estimates are somewhat smaller than in the British data. For example, the coefficient for height for the PPVT is 0.069 , in contrast to the coefficient of 0.132 for the EPVT taken by 5 -year-olds in the BCS. The addition of extended controls reduces the height coefficients to approximately 75 percent of their original values; adding mother fixed effects reduces coefficients to approximately half of their original values. However, with the exception of the digit span test, a child's height remains a significant correlate of his or her test scores, even in the presence of mother fixed effects. The height coefficients in column 3 are identified entirely off of between-sibling differences in height for age $z$-scores at age 5 and differences in their test scores. It is not possible to attribute either the attenuation of the coefficients in the presence of mother effects or their continued significance to a child's environment, genes, or gene-environment interactions. Siblings could differ in their heights and their test scores because the household environment one was born into could have been healthier and more stable in a manner not captured by our extended controls. Differences in heights could also be due to differences in the genetic material obtained from parents, or the interaction of the two. Without more information, it is not possible to say more than this. However, we can say that, even when we control for the genetic material siblings share and for that part of their home environment that is constant, children who were taller at ages 5 and 6 outperform shorter siblings on cognitive tests throughout childhood.

One possible explanation for the results discussed above is that taller 
children may be provided with greater levels of cognitive stimulation at school, possibly even as early as kindergarten. Teachers may pay more attention to taller children, or taller children may be more likely to be enrolled in school earlier than shorter children of the same age. However, evidence from the 3-year-old children from the Fragile Families study indicates that the association between height and cognitive ability appears before children reach school-going age. A one standard deviation increase in height is associated with a 5-10 percent of a standard deviation increase in the PPVT score at age 3. Estimates of separate regressions for boy and girls (not shown) yield similar results. Including extended controls (which, in this case, include the mother's own PPVT score) reduces but does not eliminate the association between heights and test scores. These results indicate that the correlation between height and cognitive ability is present before any potential differential treatment of taller children in school. ${ }^{12}$ That the associations between height and test scores do not systematically rise with age suggests that these associations are not magnified by the behaviors of teachers or parents later in life.

We also use data on the Children of the NLSY to examine the extent to which height differences explain differences in test scores across racial and ethnic groups in the United States. Estimating separate height coefficients for Hispanic, African American, and white non-Hispanic children in regressions that also contain a quartic in age at testing, indicators for race (African American) and ethnicity (Hispanic), and indicators for the year the test was taken, we find no significant differences in height premia between white, African American, and Hispanic children. For all groups, the height premium is significant for PIAT mathematics, reading recognition, reading comprehension, and digit span tests, with coefficients on height for age $z$-scores at age 5 on the order of $0.05-$ 0.08 for all three groups. Hispanic and African American Children of the NLSY on average have lower scores for all these tests in the absence of height measures. Inclusion of height for age $z$-scores does nothing to the coefficients on race and ethnicity. Not only are they not significantly different with and without controls for height, the point estimates are also almost identical. Within a group, height provides a marker for cognitive function, but height does not explain differences in scores between groups.

Other evidence indicates that the association between height and cognitive ability persists through life. Abbott et al. (1998) document a significant correlation between height of men in midlife and their cog-

\footnotetext{
${ }^{12}$ There is only limited evidence on the association between height and cognitive ability at ages younger than 3. However, one study of Indian children found that the length of 5-12-month-old infants is associated with measures of information processing speed (Rose 1994).
} 
nitive performance after age 70 . Even after adjustment for education and father's occupation, they find a strong and significant association between height and cognitive function in old age. Case and Paxson (2008) similarly document a strong positive association between height and cognition among older men and women followed in the U.S. Health and Retirement Study.

Height, Cognitive Ability, and Earnings

We use data from the British birth cohorts to reexamine the height premia in earnings presented in table 1, drawing on the information we have on cognitive ability and family background. Table 6 presents the results of regressions of the logarithm of average hourly earnings on adult height. Panel A shows results for men and women in the 1970 BCS and panel B for the 1958 NCDS. We restrict our sample to individuals who took cognitive tests at two points in childhood: ages 5 and 10 for the BCS cohort and ages 7 and 11 for the NCDS. The BCS sample contains one observation per individual: both height and average hourly earnings are reported by the individual at age 30. The NCDS sample contains up to two observations on average hourly earnings per individual: one from the age 33 survey and another from the age 42 survey. For the NCDS, we use the value of height from the age 33 survey, which was measured during a medical examination. Columns 1 and 4 of table 6 repeat the coefficients shown for the log of average hourly earnings in table 1.

Looking first at the results for the BCS cohort, in panel A, we find that test scores are jointly highly significant in the BCS earnings equations, with $F$-tests of 31.1 for men and 38.5 for women. Inclusion of these cognitive test scores reduces the size of the height coefficients by more than 50 percent and renders them statistically insignificant. Both test scores and height are correlated with family background, and it is interesting to see the extent to which family background can explain the height premia. The inclusion of personal and parental background characteristics, with no controls for test scores, also reduces the height premia in earnings in the BCS cohort, more so for men than for women. This reduction in the height premia, in the presence of extended controls, is not surprising: if height is a marker for cognitive ability, then including determinants of cognitive ability (parents' education and cohort members' early-life health, e.g.) should weaken the association between height and earnings. When both test scores and background characteristics are controlled for (cols. 4 and 8), we again find no evidence of a height premium in earnings. Both the test scores and background measures are jointly significant, although the $F$-statistics for the test scores are substantially larger than those for the extended back- 


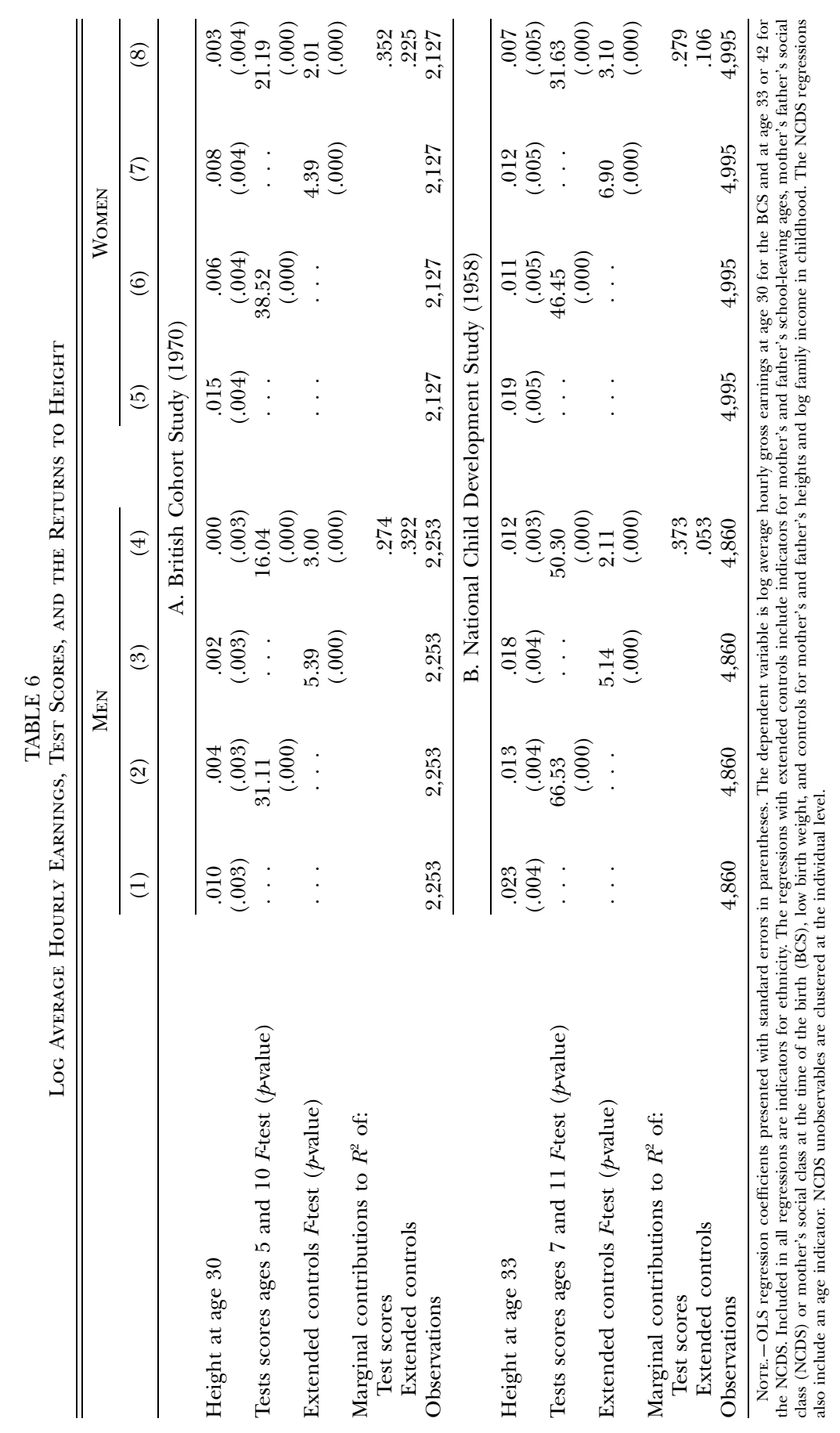


ground controls. For the BCS, the marginal contribution of the test scores to the $R^{2}$ of the regressions is similar in magnitude to the marginal contribution for the extended controls.

Panel B repeats this analysis for the NCDS. In general, the coefficients on height are larger than they were using the BCS, possibly because, with measured rather than self-reported adult heights, there may be less attenuation bias due to measurement error. ${ }^{13}$ Even after the inclusion of controls for test scores, background characteristics, and the combination of the two, the height premium in average hourly earnings for men (but not for women) is still statistically significant. However, the inclusion of test scores and extended controls reduces the height premium in average hourly earnings by 48 percent for men and 63 percent for women. The NCDS results differ from the BCS results in that the marginal contribution of test scores to the $R^{2}$ of the earnings equation is substantially larger for both men and women $(0.373,0.279)$ than the marginal contribution of the extended controls $(0.053,0.106){ }^{14}$

On average, women earn less than men in both birth cohorts. However, the height difference between men and women does not explain women's lower earnings. When we combine the samples of men and women and estimate a regression of log hourly earnings on an indicator that the cohort member is male, controlling for height, cognitive ability, and family background, the wage premium for men in the 1958 birth cohort is 40 percent, with or without controlling for height in the regression. In the 1970 birth cohort, the male wage premium is lower, at 17 percent, with or without the inclusion of height.

\section{Growth, Cognitive Ability, and Earnings}

The framework developed above suggests that patterns of growth during childhood contain information about children's endowments. One implication of the model is that if both cognitive ability and growth are driven by the same underlying endowment, then cognitive ability in childhood should be correlated with the timing of the adolescent growth

\footnotetext{
${ }^{13}$ Because members of the NCDS were measured at age 33 and self-reported their heights at age 42 , we can examine the extent to which self-reports would lead to attenuation bias in this sample. Repeating regressions reported in table 1 for log hourly earnings in the NCDS, but using self-reported heights in place of measured heights, we find that the coefficient for men's heights falls from 0.023 to 0.018 . The coefficient on women's heights remains unchanged at 0.019 . (Women in the NCDS are 10 percentage points less likely than men to report themselves as taller at age 42 than they were measured to be at age 33.)

${ }^{14}$ The key difference in this result between the cohort studies is that father's schoolleaving age is a much stronger predictor of earnings among members of the 1970 cohort than among members of the 1958 cohort.
} 
spurt. Specifically, children who have higher cognitive test scores should experience their adolescent growth spurts at younger ages.

We use data from the NCDS to examine whether cognitive test scores at age 11 are associated with the timing of the adolescent growth spurt. We first regress individual test scores on growth between ages 11 and 16 and then on growth between ages 16 and 33. We estimate separate models for boys and girls. Because girls begin their adolescent growth spurts earlier than boys, the associations between growth at different ages and cognitive ability should vary by sex. We also estimate these models with and without a set of extended controls for family characteristics that measure parents' height and educational attainment, economic status, and measures of a cohort member's health in early life, specifically whether the child was born at low weight and whether his or her mother smoked during pregnancy. We expect these extended controls to be associated with both test scores and the timing of the adolescent growth spurt.

Columns 1-4 of table 7 present evidence that the timing of growth is a marker of cognitive function in boys. Boys who grew more from age 11 to 16 had, on average, higher cognitive test scores at age 11 . The results in column 1 indicate that each inch of growth in early adolescence is associated with an increase in test scores at age 11 of between 2 and 3 percent of a standard deviation. In contrast, boys who grew more between ages 16 and 33-indicating a later adolescent growth spurt-had lower average test scores at age 11. Each inch of growth in late adolescence is associated with a decline in test scores at age 11 of between 3.1 and 3.8 percent of a standard deviation. As expected, the sizes of these associations for both growth periods are smaller in absolute value when extended controls that may be determinants of both the tempo of growth and cognitive function are included.

The results for girls differ from those for boys, in ways that make sense given girls' earlier adolescent growth spurts. Height gains from 11 to 16 are negatively associated with test scores at age 11 , with each inch of height associated with a decline in test scores ranging from 2.2 to 3.0 percent of a standard deviation. Height gains from 16 to 33 have even larger negative associations with test scores, with coefficients of -5.3 to -6.1 . The girls with the highest test scores at age 11 had already attained a large share of their adult heights, so that growth from 11 to 16 signals relatively "late" growth. ${ }^{15}$ By age 16 , most girls have attained

\footnotetext{
${ }^{15}$ Ideally, we would have height measurements for girls at the age of 8 or 9 , just before the adolescent growth spurt, and at age 12 or 13, just after the average age of peak height velocity for girls. We expect that test scores would be positively associated with growth from age 8 to 12 and negatively associated with growth from age 12 to 16 . We are, however, unable to test this with the NCDS.
} 


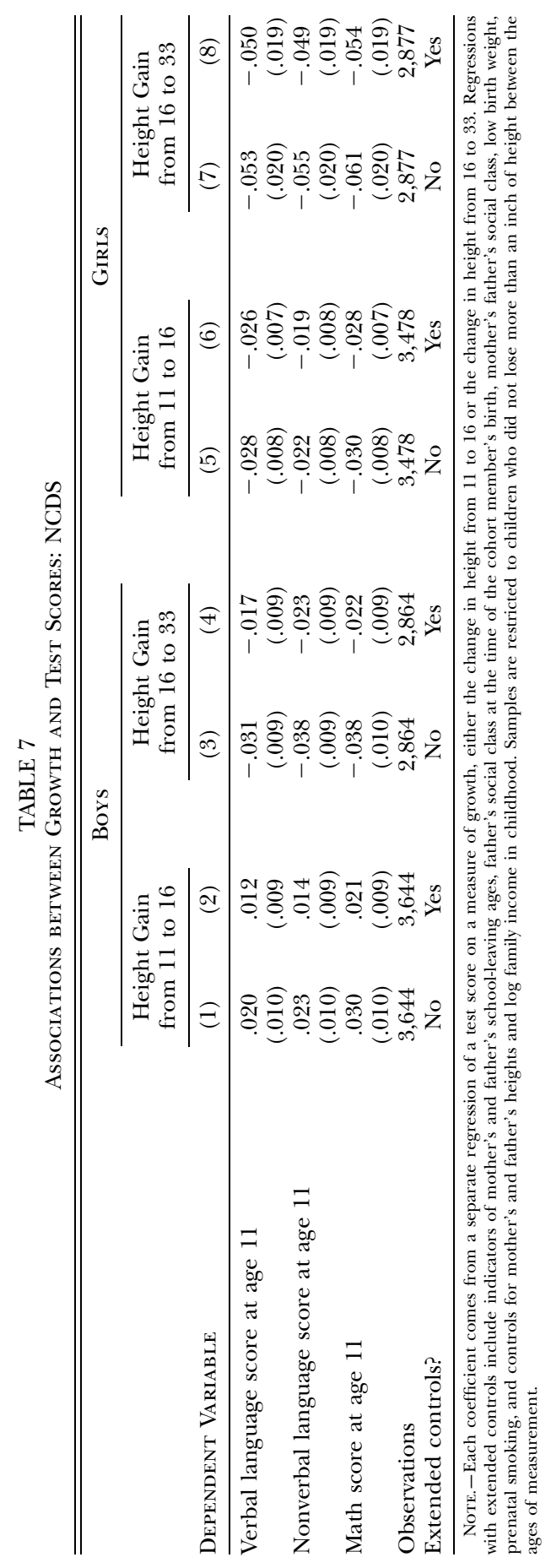


their adult height. Growth from age 16 to 33 is a signal of more severe deprivation than is the case for boys.

The results in table 7 indicate that, for both boys and girls, the patterns of heights over childhood convey information about children's cognitive ability. If so, then heights at different periods in childhood, even when we control for adult height, should be associated with earnings in adulthood. Our reading of the literature from human biology indicates that height during the adolescent growth spurt is likely to be an especially good marker of a child's endowment. Heights in young childhood may also convey more information about early-life experiences than height in middle childhood or adulthood. Furthermore, if the associations between heights and earnings reflect cognitive ability, then the inclusion of measures of cognitive ability in earnings regressions should reduce the associations between heights and earnings.

To examine these hypotheses, in table 8 we use the NCDS to estimate regressions of the logarithm of average hourly earnings of men and women on their heights at ages $7,11,16$, and 33, with and without controls for test scores and other extended controls. Our results for men in column 1 indicate that heights at ages 7 and 16 are significantly associated with average hourly earnings, with coefficients of 0.022 and 0.017 , respectively. The coefficients for heights at ages 11 and 33 are much smaller (both 0.001) and insignificant, and the hypothesis that the four height coefficients are equal can be strongly rejected. The inclusion of test scores at ages 7 and 11 produces reductions in the coefficients for heights at ages 7 and 11: the coefficient on height at age 7 is not significant, and that for height at age 16 is reduced by 24 percent. The inclusion of extended controls alone has much smaller effects, and the coefficients with both test scores and extended controls are much the same as with test scores alone. These results are consistent with those in table 6 , which showed that, with height at age 33 , the height premium in earnings for men is reduced but not eliminated when we control for childhood test scores.

These reductions in the height premia in earnings are much more pronounced if we also control for test scores at age 16. For example, a variant of column 2 of table 8 that includes age 16 test scores yields a coefficient on height at age 16 of 0.007 , with a standard error of 0.006 . We have chosen not to control for age 16 test scores, since it is possible that taller adolescent boys, because of their heights, have more positive adolescent experiences, which could result in higher test scores at age 16 (Persico et al. 2004). We discuss this hypothesis in more detail below.

The associations between heights at different points in childhood and earnings are less informative for women than for men. Heights at ages 7 and 33 take the largest coefficients, although neither is precisely estimated, and the hypothesis that the coefficients on heights are identical 


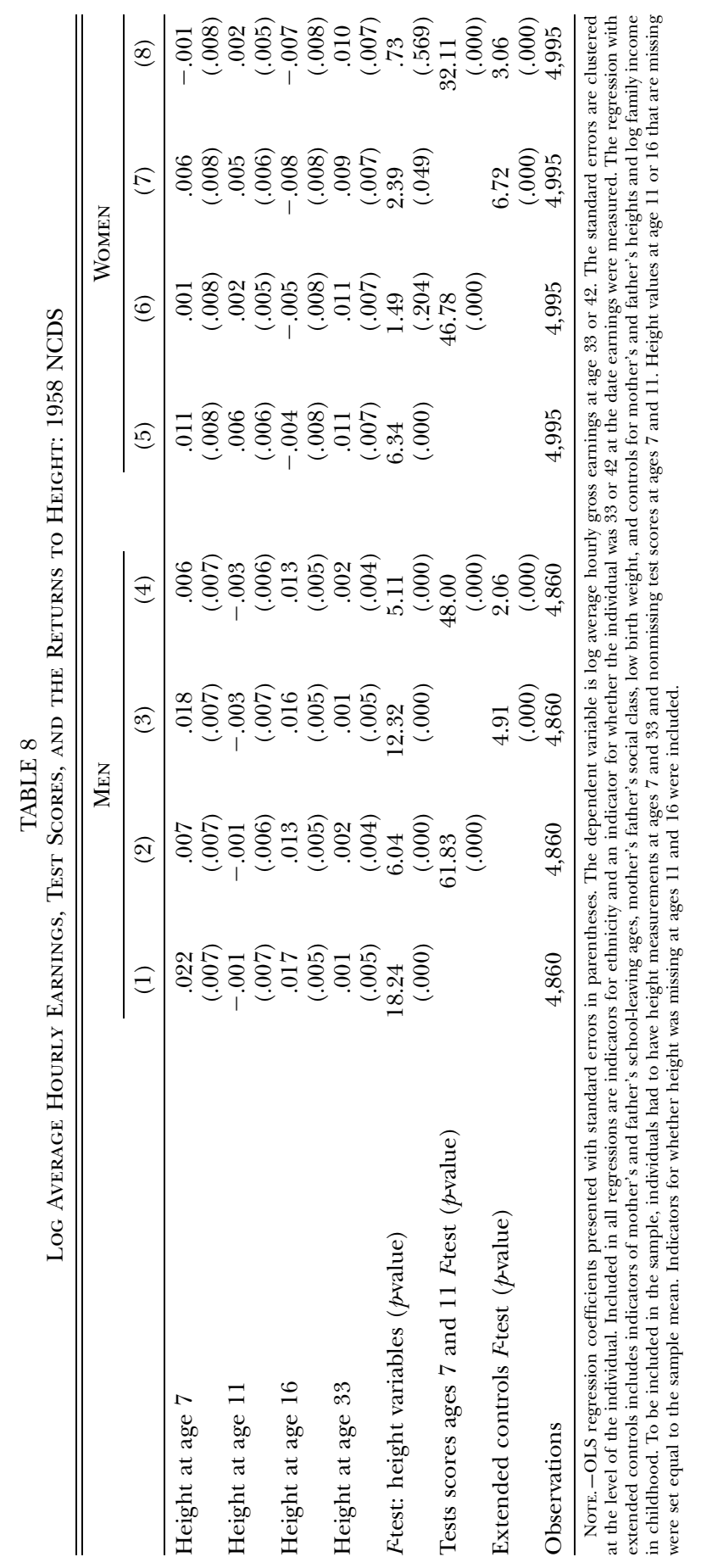


to each other cannot be rejected. The height measures are jointly significant but are no longer so once test scores are included in the models. We suspect that the differences in results between men and women result from the fact that the timing of the NCDS surveys is not ideal to capture the timing of girls' adolescent growth spurts. However, in the absence of data collected at different ages, it is not possible to examine whether this is the case.

\section{Cognitive Ability or Teen Social Experiences?}

Persico et al. (2004) also use data for males from the NCDS and the NLSY to examine the determinants of the height premium in earnings. They document that fact that, in regressions of log average hourly earnings of men at age 33 on height at age 16 and height at age 33, only the coefficient on height at age 16 is large and significant. They also estimate regressions in which average hourly earnings is regressed on heights at ages $7,11,16$, and 33 , and they find that only height at age 16 predicts earnings. Their explanation is that males who are taller in adolescence have different social experiences in adolescence than their shorter peers. Specifically, they are more likely to engage in clubs and other social activities that may build productive human capital.

Our results differ from those of Persico et al. in a number of ways. The first is that we find that men's adult earnings are strongly associated with heights at ages 7 and 16, not just at age 16. Using data from the NCDS, they find that in a regression of earnings on all heights and controls for parental and family background, height at age 7 takes a coefficient of 0.003 with a standard error of 0.011 (2004, 1033, table 4). In contrast, we find that, in a similar regression also using the NCDS, height at age 7 takes a coefficient of 0.018 with a standard error of 0.007 (col. 3 of table 8). We can replicate their results if we do not use information on earnings at age 42, and we restrict our sample to white men who are employed full-time at age 33. We are more confident in the results presented here, which are based on a substantially larger sample (4,860 observations vs. 1,617 observations).

More important, we offer a different interpretation of the source of the association between height and earnings than Persico et al. They state that "conditional on other observables, an individual's heights at various ages are exogenously given" $(2004,1030, \mathrm{n} .15)$. This assumption is necessary if one is to conclude that teen height per se has an effect on human capital formation and subsequent earnings. However, the timing of adolescent growth spurts, with young adults from wealthier and healthier backgrounds reaching their growth spurts earlier, calls this key assumption into question. The evidence presented here-that boys' heights are associated with the economic status of their fathers, 
especially at age 16; that heights are associated with cognitive test scores from very early ages; and that test scores in childhood predict the timing of the adolescent growth spurt-indicates that adolescent height serves as a marker of much more than teen social experience. Our evidence also implies that interventions that increase heights-such as the use of hormone growth replacement therapy discussed by Persico et al.-are unlikely to have a large impact on earnings in adulthood unless they also improve cognitive ability.

\section{Conclusion}

Our evidence supplies a rationale for why economic returns to height continue to be observed, even in wealthy countries in which increasingly small fractions of workers do physically demanding work. It also provides an alternative to explanations for the height premium that rely on pure discrimination or social stigma against shorter individuals.

The results of this paper suggest several areas for further research. One is the study of the long-run effects of improved prenatal and childhood nutrition. Evidence from the medical literature indicates that the prenatal environment and nutrition in childhood may play an important role in determining both height and cognitive ability. However, we know of no studies from industrialized countries that have tracked children over time to see how prenatal or early nutritional interventions affect cognitive functioning and labor market outcomes in adulthood. For the design of effective interventions, it is also essential to know whether there are specific windows of time-in utero or at different stages of a child's development-in which health and nutrition interventions have the biggest impact on cognitive outcomes that are rewarded in the labor market. More generally, much of the research on nutrition, child growth, and cognitive function that has been conducted to date provides evidence on very poor settings, where children may face large deficits in calories and protein and a heavy disease burden. The extent to which insults in utero and childhood illness and nutrition affect cognitive function in developed countries is not well understood. Research in wealthier settings is also clearly warranted.

To the extent that height is a marker of cognitive function, employers might statistically discriminate in favor of taller workers, at least until employers have time to learn about employees' abilities. It would be interesting to follow a cohort regularly, from the time its members enter the labor force through to late middle age, to see whether the height premium is largest early on in workers' tenure on the job. 


\section{References}

Abbott, Robert D., et al. 1998. "Height as a Marker of Childhood Development and Late-Life Cognitive Function: The Honolulu-Asia Aging Study." Pediatrics 102 (September): 602-9.

Almond, Douglas. 2006. "Is the 1918 Influenza Pandemic Over? Long-Term Effects of In Utero Influenza Exposure in the Post-1940 U.S. Population." J.P.E. 114 (August): 672-712.

Beard, Albertine S., and Martin J. Blaser. 2002. "The Ecology of Height: The Effect of Microbial Transmission on Human Height." Perspectives Biology and Medicine 45 (Autumn): 475-99.

Behrman, Jere R., and Mark R. Rosenzweig. 2004. "Returns to Birthweight." Rev. Econ. and Statis. 86 (May): 586-601.

Berger, Abi. 2001. "Insulin-Like Growth Factor and Cognitive Function." British Medical J. 322 (January 27): 203.

Black, Sandra E., Paul J. Devereux, and Kjell G. Salvanes. 2007. "From the Cradle to the Labor Market? The Effect of Birth Weight on Adult Outcomes." Q.J.E. 122 (February): 409-39.

Brown, Rosalind S., and Laurie A. Demmer. 2002. "The Etiology of Thyroid Dysgenesis-Still an Enigma after All These Years." J. Clinical Endocrinology and Metabolism 87 (September): 4069-71.

Case, Anne, and Christina Paxson. 2008. "Height, Health and Cognitive Function at Older Ages." A.E.R. Papers and Proc. 98 (May).

Centers for Disease Control. 1977. "Data from the National Health Survey. NCHS Growth Curves for Children, Birth-18 Years, United States." Vital and Health Statistics, ser. 11, no. 165 (November).

- 2002. "2000 CDC Growth Charts for the United States: Methods and Development." Vital and Health Statistics, ser. 11, no. 246 (May).

Crimmins, Eileen M., and Caleb E. Finch. 2006. "Infection, Inflammation, Height and Longevity." Proc. Nat. Acad. Sci. 103 (January 10): 498-503.

Dunn, L. M., and L. M. Dunn. 1997. The Peabody Picture Vocabulary Test. 3rd ed. Circle Pines, MN: American Guidance Service.

Ekdahl, C. T., J. H. Claasen, S. Bonde, Z. Kokaia, and O. Lindvall. 2003. "Inflammation Is Detrimental for Neurogenesis in Adult Brain.” Proc. Nat. Acad. Sci. 100 (November 11): 13632-37.

Ericson, Anders, and Bengt Kallen. 1998. "Very Low Birthweight Boys at the Age of 19." Archives Disease Childhood Fetal and Neonatal Ed. 78 (May): F171-F174.

Eveleth, Phyllis B., and James M. Tanner. 1990. "Rate of Maturation: Population Differences in Skeletal, Dental and Pubertal Development." In Worldwide Variation in Human Growth. 2nd ed. Cambridge: Cambridge Univ. Press.

Freedman, D. G. 1979. Human Sociobiology. New York: Free Press.

Gowin, E. B. 1915. The Executive and His Control of Men. New York: Macmillan.

Grantham-McGregor, Sally. 2002. "Linear Growth Retardation and Cognition." Lancet 359 (February 16): 542.

Hack, M., M. Schluchter, L. Cartar, M. Rahman, L. Cuttler, and E. Borawski. 2003. "Growth in Very Low Birth Weight Infants to Age 20 Years." Pediatrics 112 (July): e30-e38.

Haddad, Lawrence J., and Howarth E. Bouis. 1991. "The Impact of Nutritional Status on Agricultural Productivity: Wage Evidence from the Philippines." Oxford Bull. Econ. and Statis. 53 (February): 45-68.

Hensley, Wayne E. 1993. "Height as a Measure of Success in Academe." Psychology: J. Human Behavior 30 (1): 40-46.

Herman-Giddens, M. E., et al. 1997. "Secondary Sexual Characteristics and Men- 
ses in Young Girls Seen in Office Practice: A Study from the Pediatric Research in Office Settings Network." Pediatrics 99 (April): 505-12.

Holding, P. A., and R. W. Snow. 2001. "Impact of Plasmodium Falciparum Malaria on Performance and Learning: Review of the Evidence." American J. Tropical Medicine and Hygiene 64 (January-February; suppl.): 68-75.

Husén, T. 1959. Psychological Twin Research. New York: Free Press.

Institute of Medicine. 2001. "Reproductive and Developmental Effects." In Clearing the Smoke: Assessing the Science Base for Tobacco Harm Reduction, edited by Kathleen Stratton, Padma Shetty, Robert Wallace, and Stuart Bondurant. Washington, DC: Nat. Acad. Press.

Klein, R. E., H. E. Freeman, J. Kagan, C. Yarbrough, and J. P. Habicht. 1972. "Is Big Smart? The Relation of Growth to Cognition." J. Health and Soc. Behavior 13 (September): 219-25.

Komlos, J., J. M. Tanner, P. S. W. Davies, and T. Cole. 1992. "The Growth of Boys in the Stuttgart Carlschule, 1771-93." Ann. Human Biology 19 (MarchApril): 139-52.

Kretchmer, Norman, John L. Beard, and Susan Carlson. 1996. "The Role of Nutrition in the Development of Normal Cognition." American J. Clinical Nutrition 63 (June): 997S-1001S.

Lechelt, Eugene C. 1975. "Occupational Affiliation and Ratings of Physical Height and Personal Esteem." Psychological Reports 36 (June): 943-46.

Li, Leah, Orly Manor, and Chris Power. 2004. "Early Environment and Childto-Adult Growth Trajectories in the 1958 British Birth Cohort." American J. Clinical Nutrition 80 (July): 185-92.

Loh, Eng Seng. 1993. "The Economic Effects of Physical Appearance.” Soc. Sci. Q. 74 (June): 420-38.

Lynn, R. 1989. "A Nutrition Theory of the Secular Increases in Intelligence, Positive Correlation between Height, Head Size and IQ." British J. Educ. Psychology 59 (November): 372-77.

Magnusson, Patrik K. E., Finn Rasmussen, and Ulf B. Gyllensten. 2006. "Height at Age 18 Years Is a Strong Predictor of Attained Education Later in Life: Cohort Study of Over 950000 Swedish Men." Internat. J. Epidemiology 35 (January): 658-63.

Martorell, R., J. Behrman, R. Flores, and A. Stein. 2005. "Rationale for a Followup Study Focusing on Economic Productivity." Food and Nutrition Bull. 26 (June; suppl. 1): S5-S14.

Martorell, R., L. Kettel Khan, and D. G. Schroeder. 1994. "Reversibility of Stunting: Epidemiological Findings in Children from Developing Countries." European J. Clinical Nutrition 48 (February): S45-S57.

Martorell, R., J. Rivera, and H. Kaplowitz. 1990. "Consequences of Stunting in Early Childhood for Adult Body Size in Rural Guatemala." Annales Nestlé 48: 85-92.

Murphy, Kevin, and Robert Topel. 1990. "Efficiency Wages Reconsidered: Theory and Evidence." In Advances in the Theory and Measurement of Unemployment, edited by Yoram Weiss and Gideon Fishelson. London: Macmillan.

Persico, Nicola, Andrew Postlewaite, and Dan Silverman. 2004. "The Effect of Adolescent Experience on Labor Market Outcomes: The Case of Height." J.P.E. 112 (October): 1019-53.

Reichman, Nancy, Julien Teitler, Irwin Garfinkel, and Sara McLanahan. 2001. "Fragile Families: Sample and Design." Children and Youth Services Rev. 23 (April): 303-26. 
Resnik, Robert. 2002. "Intrauterine Growth Restriction.” Obstetrics and Gynecology 99 (March): 490-96.

Richards, Marcus, Rebecca Hardy, Diana Kuh, and Michael E. J. Wadsworth. 2002. "Birthweight, Postnatal Growth and Cognitive Function in a National U.K. Birth Cohort." Internat. J. Epidemiology 31 (April): 342-48.

Romano, E., R. E. Tremblay, A. Farhat, and S. Cote. 2006. "Development and Prediction of Hyperactive Symptoms from 2 to 7 Years in a Population Based Sample." Pediatrics 117 (June): 2101-10.

Rose, S. A. 1994. "Relation between Physical Growth and Information Processing in Infants Born in India." Child Development 65 (June): 889-902.

Satyanarayana, K., et al. 1989. "The Adolescent Growth Spurt of Height among Rural Indian Boys in Relation to Childhood Nutritional Background: An 18 Year Longitudinal Study.” Ann. Human Biology 16 (July-August): 289-300.

Silventoinen, Karri. 2003. "Determinants of Variation in Adult Body Height." J. Biosocial Sci. 35 (April): 263-85.

Slotkin, T. A. 1998. "Fetal Nicotine or Cocaine Exposure: Which One Is Worse?" J. Pharmacology and Experimental Therapeutics 285 (June): 931-34.

Steckel, Richard H. 1995. "Stature and the Standard of Living." J. Econ. Literature 33 (December): 1903-40.

Strauss, John, and Duncan Thomas. 1998. "Health, Nutrition and Economic Development." J. Econ. Literature 36 (June): 766-817.

Sun, Shumei S., et al. 2002. "National Estimates of the Timing of Sexual Maturation and Racial Differences among US Children." Pediatrics 110 (January): 911-19.

Sundet, J. M., K. Tambs, J. R. Harris, P. Magnus, and T. M. Torjussen. 2005. "Resolving the Genetic and Environmental Sources of the Correlation between Height and Intelligence: A Study of Nearly 2600 Norwegian Male Twin Pairs." Twin Res. and Human Genetics 8 (August): 307-11.

Tanner, James M. 1979. "A Concise History of Growth Studies from Buffon to Boas." In Human Growth, vol. 3, Neurobiology and Nutrition, edited by Frank Falkner and James M. Tanner. New York: Plenum.

Weitzman, M., S. Gortmaker, and A. Sobol. 1992. "Maternal Smoking and Behavior Problems of Children." Pediatrics 90 (September): 342-49.

Wilson, Paul R. 1968. "Perceptual Distortion of Height as a Function of Ascribed Academic Status.” J. Soc. Psychology 74 (February): 97-102.

Wong, William W., Kenneth C. Copeland, Albert C. Hergenroeder, Rebecca B. Hill, Janice E. Stuff, and Kenneth J. Ellis. 1999. "Serum Concentrations of Insulin, Insulin-Like Growth Factor-I and Insulin-Like Growth Factor Binding Proteins Are Different between White and African American Girls." J. Pediatrics 135 (September): 296-300.

Wong, William W., et al. 1998. "Serum Leptin Concentrations in Caucasian and African-American Girls.” J. Clinical Endocrinology and Metabolism 83 (October): 3574-77.

Young, Thomas J., and Laurence A. French. 1996. "Height and Perceived Competence of U.S. Presidents." Perceptual and Motor Skills 82 (June): 1002. 